\title{
COD FRACTIONS IN MECHANICAL-BIOLOGICAL WASTEWATER TREATMENT PLANT
}

\author{
Ewelina PŁUCIENNIK-KOROPCZUK ${ }^{1}$, Anita JAKUBASZEK ${ }^{2}$, \\ Sylwia MYSZOGRAJ ${ }^{3}$, Sylwia USZAKIEWICZ ${ }^{4}$ \\ 1,2,3 University of Zielona Gora, Zielona Góra, Poland \\ ${ }^{4}$ Student University of Zielona Gora, Zielona Góra, Poland
}

\begin{abstract}
The paper presents results of studies concerning the designation of COD fraction in the raw, mechanically treated and biologically treated wastewater. The test object was a wastewater treatment plant with the output of over 20,000 PE. The results were compared with data received in the ASM models. During investigation following fractions of COD were determined: dissolved non-biodegradable $\mathrm{S}_{\mathrm{I}}$, dissolved easily biodegradable $\mathrm{S}_{\mathrm{S}}$, in organic suspension slowly degradable $\mathrm{X}_{\mathrm{S}}$ and in organic suspension nonbiodegradable $\mathrm{X}_{\mathrm{I}}$. Methodology for determining the COD fraction was based on the guidelines ATV-A 131. The real percentage of each fraction in total COD in raw wastewater are different from data received in ASM models.
\end{abstract}

Keywords: wastewater, COD fractions, ASM models, organic substances biodegradable and non-biodegradable

\section{INTRODUCTION}

In the design and optimisation of biological wastewater treatment processes, it is very important to determine the biodegradability of contaminants with taking into account the ratios of contained by them compounds responsive and resistant to

\footnotetext{
${ }^{1}$ Corresponding author: University of Zielona Gora, Institute of Environmental Engineering, Szafrana st 15, 65-246 Zielona Góra, Poland, e-mail:e.pluciennik@iis.uz.zgora.pl, tel. +48683282396
} 
decomposition, and the influence of wastewater constituents on the course of unit processes. Detailed characterisation of organic contaminants is of increasing significance also in sludge stabilisation processes and problems related to sludge liquors forming in wastewater treatment plants $[5,11,12,13,18,20]$. The index $\mathrm{BOD}_{5}$, so commonly used in designing technology sewage treatment systems, only provides information about easily biodegradable contaminant content. The index COD, with division into fractions, is currently presented as the most appropriate for the characterisation of organic substrates present in wastewater, because it makes it possible to obtain information on biodegradability of organic contaminants, both in dissolved and suspension form $[1,3,16,25,26]$.

The basic division of total COD $[4,17,19]$ in raw wastewater into fractions used in designing and modelling of wastewater treatment systems is presented in Fig. 1. The percentage ratio of the suspension fraction in total COD of raw household wastewater is $65 \div 79 \%$ and dissolved $-21 \div 35 \%[4,17,19]$.

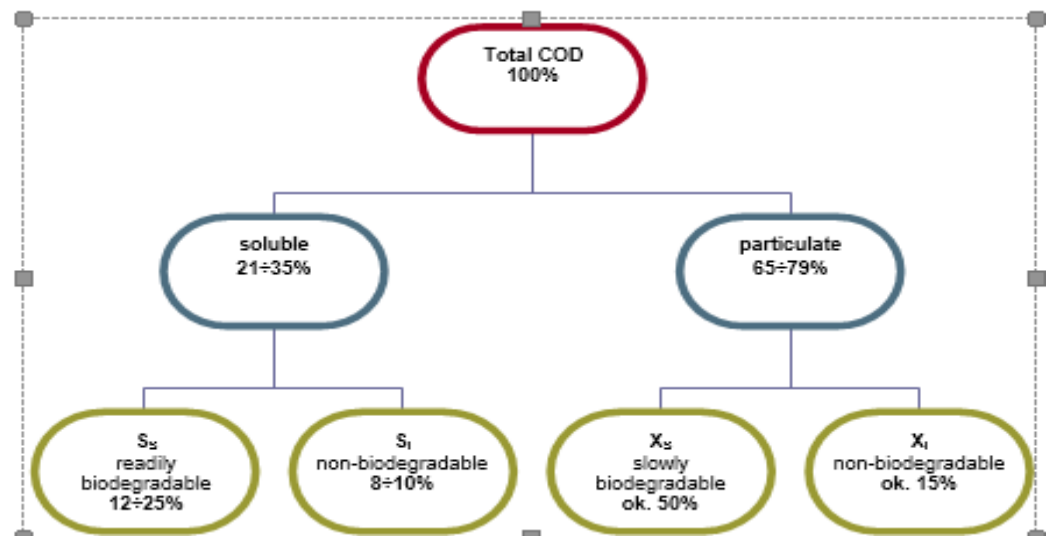

Fig. 1. Basic division of total COD in raw wastewater into fractions $[4,17,19]$

\section{COD FRACTION IN BIOKINETIC ASM MODELS}

The International Association on Water Pollution Research and Control (IAWPRC) work group published in 1987 first version of the model named Activated Sludge Model No.1 [10, 15, 21]. ASM1 model enables the simulation of the processes of removal of organic compounds and nitrogen compounds from wastewater, with taking into account unit processes which occur both in wastewater, as well as active sludge [7, 10, 14, 27]. The next version of the Model was ASM2. A novelty in the ASM2 model is the isolation from the group of active sludge microorganisms ones with the ability of phosphorus accumulation by polyphosphate storage $[6,8,10]$.

The ASM1 model includes eight unit processes which are divided into 3 groups: hydrolysis processes, organic substance decomposition processes occurring in the 
presence of heterotrophic bacteria and processes conducted by autotrophic bacteria (nitrificants). The division of organic substances in the ASM2 model is much more complex than in the ASM1 version, because it takes into account 19 constituents used in wastewater and active sludge characterisation. Ten of them relate to insoluble constituents, nine to soluble ones $[2,6,9,10]$.

The constituents of total COD according to the ASM1 and ASM2 models are presented respectively by the equations (2.1) and (2.2):

$$
\mathrm{COD}_{\text {tot. }}=\mathrm{S}_{\mathrm{S}}+\mathrm{S}_{\mathrm{I}}+\mathrm{X}_{\mathrm{S}}+\mathrm{X}_{\mathrm{I}}+\mathrm{X}_{\mathrm{H}}+\mathrm{X}_{\mathrm{A}}+\mathrm{X}_{\mathrm{P}}, \mathrm{gO}_{2} / \mathrm{m}^{3}
$$

$\mathrm{COD}_{\text {tot. }}=\mathrm{S}_{\mathrm{A}}+\mathrm{S}_{\mathrm{F}}+\mathrm{S}_{\mathrm{I}}+\mathrm{X}_{\mathrm{S}}+\mathrm{X}_{\mathrm{I}}+\mathrm{X}_{\mathrm{H}}+\mathrm{X}_{\mathrm{A}}+\mathrm{X}_{\mathrm{PAO}}+\mathrm{X}_{\mathrm{PHA}} \mathrm{gO}_{2} / \mathrm{m}^{3}$

where:

$\mathrm{S}_{\mathrm{s}} \quad$ - soluble readily biodegradable substrates, $\mathrm{gO}_{2} / \mathrm{m}^{3}$,

$\mathrm{S}_{\mathrm{A}}$ - fermentation products (acetate) $\mathrm{gO}_{2} / \mathrm{m}^{3}$,

$\mathrm{S}_{\mathrm{F}}$ - fermentable, readily biodegradable organic substrates $\mathrm{gO}_{2} / \mathrm{m}^{3}$,

$\mathrm{S}_{\mathrm{I}} \quad$ - inert soluble organic material, $\mathrm{gO}_{2} / \mathrm{m}^{3}$,

$\mathrm{X}_{\mathrm{I}} \quad$ - inert particulate organic material, $\mathrm{gO}_{2} / \mathrm{m}^{3}$,

$\mathrm{X}_{\mathrm{S}}$ - particulate slowly biodegradable substrates, $\mathrm{gO}_{2} / \mathrm{m}^{3}$,

$\mathrm{X}_{\mathrm{H}}$ - heterotrophic organisms, $\mathrm{gO}_{2} / \mathrm{m}^{3}$,

$\mathrm{X}_{\mathrm{A}}$ - autotrophic nitrifying organisms, $\mathrm{gO}_{2} / \mathrm{m}^{3}$,

$\mathrm{X}_{\mathrm{P}} \quad$ - decay products, $\mathrm{gO}_{2} / \mathrm{m}^{3}$,

$\mathrm{X}_{\mathrm{PAO}}$ - phosphorus accumulating organisms, $\mathrm{gO}_{2} / \mathrm{m}^{3}$,

$\mathrm{X}_{\mathrm{PHA}}$ - cell internal storage product of $\mathrm{PAO}$ 's, $\mathrm{gO}_{2} / \mathrm{m}^{3}$.

When the biomass fraction is not included, both equations are simplified to the form $\mathrm{COD}_{\mathrm{tot}}=\mathrm{S}_{\mathrm{S}}+\mathrm{S}_{\mathrm{I}}+\mathrm{X}_{\mathrm{S}} \mathrm{X}_{\mathrm{I}}, \mathrm{g} / \mathrm{m}^{3}$.

The both models ASM1 and ASM2 assume that in raw wastewater fractions $X_{S}$ and $S_{S}$ are dominant, whereas in lower concentrations two other fractions, $S_{\mathrm{I}}$ and $\mathrm{X}_{\mathrm{I}}$, occur. The percentage ratios of the individual fractions in raw wastewater assumed by the ASM1 and ASM2 models are presented in Table 1 .

The ASM1 model assumes constant values of the percentage ratio of the individual fractions, whereas the ASM2 model gives ranges of percentage ratios of the individual fractions in total COD of raw sewage.

Table1. The percentage ratios of COD fractions in biokinetic models $[4,9,10]$

\begin{tabular}{|c|c|c|}
\hline \multirow{2}{*}{ COD fractions, $\%$} & \multicolumn{2}{|c|}{$\begin{array}{c}\text { The percentage ratios of the COD fractions in biokinetic } \\
\text { models }\end{array}$} \\
\cline { 2 - 3 } & ASM1 & ASM 2 \\
\hline$X_{\mathrm{S}}$ & 70 & $35 \div 75$ \\
\hline $\mathrm{S}_{\mathrm{S}}$ & 15 & $12 \div 30$ \\
\hline $\mathrm{X}_{\mathrm{I}}$ & 10 & $10 \div 15$ \\
\hline $\mathrm{S}_{\mathrm{I}}$ & 5 & $5 \div 10$ \\
\hline
\end{tabular}




\section{MATERIAL AND METHODS}

The goal of the research was to determine the actual concentrations of COD fractions in raw, mechanically treated and treated wastewater in wastewater treatment plant with the output of over $20000 \mathrm{PE}$. The results and calculations obtained have made it possible to determine percentage ratios of the individual fractions in total COD and compare the results obtained with the assumptions of the biokinetic ASM models.

\subsection{The characteristics of the research objects}

The research were conducted in mechanical-biological wastewater treatment plant with the output of $6000 \mathrm{~m}^{3} / \mathrm{d}(20000 \mathrm{PE})$. Wastewater samples were taken in designated measurement points: on the inlet (P1), after primary settling tank (P2) and on the outlet (P3). The technology diagram of the WWTP is presented in Fig. 2.

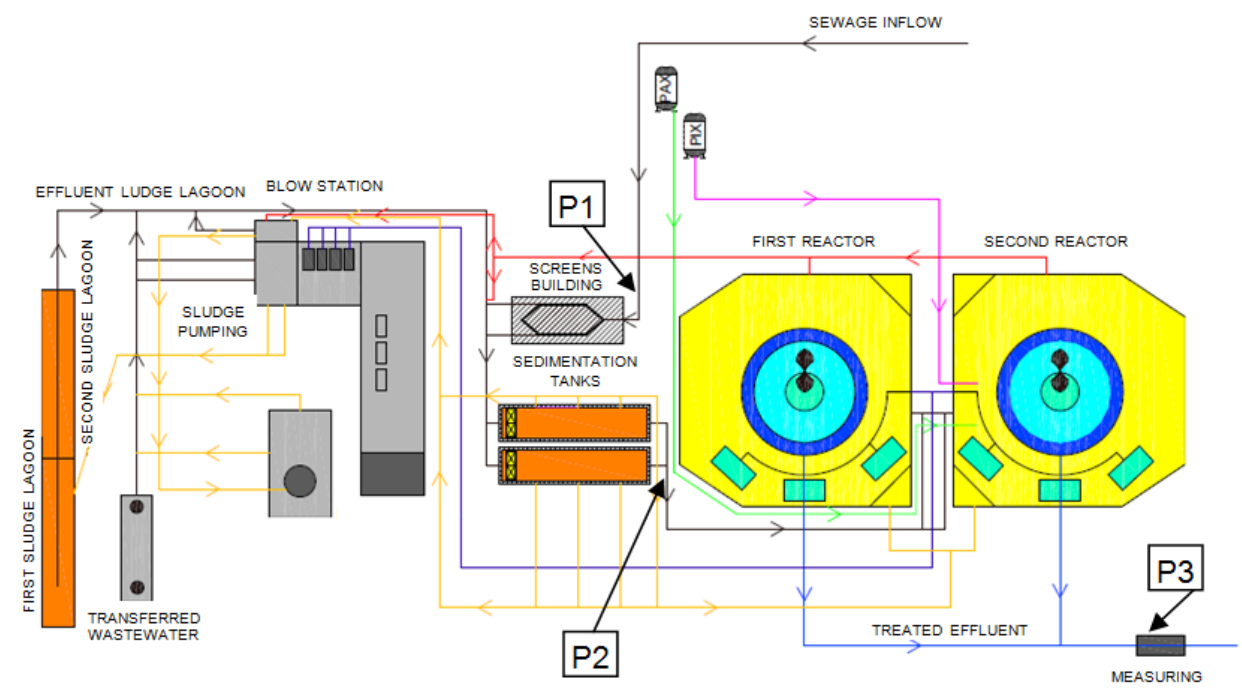

Fig. 2. The technology diagram of the WWTP

\subsection{Methodology of research}

Wastewater samples were taken in accordance with PN-ISO 5667-10:1997.

The wastewater samples included the characterisation of:

- Chemical oxygen demand, COD - with the potassium dichromate method, as per PN-74/C-04578.03, PN-ISO 6060:2006,

- Biochemical oxygen demand, BOD - with the manometric method, using the OxiTop Control OC110 measurement system made by WTW, 
The characterisations were conducted in three repetitions, in non-filtred samples and samples filtered through a $0.45 \mu \mathrm{m}$ filter.

Based on the results of $\mathrm{COD}$ and $\mathrm{BOD}_{5}$ measurements obtained, COD fractions were calculated.

The methodology of COD fraction determination has been developed on the basis of the ATV-A131 guidelines [22, 23, 24, 28].

- Total COD of raw wastewater as the sum of the fractions is determined with the equation:

$$
\mathrm{COD}_{\text {tot. }}=\mathrm{S}_{\mathrm{I}}+\mathrm{S}_{\mathrm{S}}+\mathrm{X}_{\mathrm{S}}+\mathrm{X}_{\mathrm{I}}, \mathrm{gO}_{2} / \mathrm{m}^{3}
$$

where:

$\mathrm{S}_{\mathrm{S}} \quad$ - soluble readily biodegradable substrates, $\mathrm{gO}_{2} / \mathrm{m}^{3}$,

$\mathrm{S}_{\mathrm{I}} \quad$ - inert soluble organic material, $\mathrm{gO}_{2} / \mathrm{m}^{3}$,

$\mathrm{X}_{\mathrm{S}}$ - particulate slowly biodegradable substrates, $\mathrm{gO}_{2} / \mathrm{m}^{3}$,

$\mathrm{X}_{\mathrm{I}} \quad$ - inert particulate organic material, $\mathrm{gO}_{2} / \mathrm{m}^{3}$.

- The dissolved, non-biodegradable fraction $\mathrm{S}_{\mathrm{I}}$ is termed as COD in filtered (through a $0.45 \mu \mathrm{m}$ filter) treated wastewater.

- The dissolved, easily biodegradable fraction $S_{S}$ is calculated from the difference of the concentration of dissolved organic contaminants $\mathrm{S}_{\mathrm{COD}}$ determined in filtered raw wastewater and the concentration of the dissolved non-biodegradable fraction $\left(\mathrm{S}_{\mathrm{I}}\right)$ :

$$
\mathrm{S}_{\mathrm{S}}=\mathrm{S}_{\mathrm{COD}}-\mathrm{S}_{\mathrm{I}}, \mathrm{gO}_{2} / \mathrm{m}^{3} \text {. }
$$

- The slowly biodegradable organic suspension fraction $X_{S}$ is defined as the difference of total $\mathrm{BOD}\left(\mathrm{BOD}_{\mathrm{T}}\right)$, calculated based on the $\mathrm{BOD}_{5}$ of non-filtered raw wastewater and biochemical decomposition coefficient $(\mathrm{k} 1)$ and the dissolved easily biodegradable fraction:

$$
\mathrm{X}_{\mathrm{S}}=\left(\mathrm{BZT}_{5} / \mathrm{k}_{1}\right)-\mathrm{S}_{\mathrm{S}}, \mathrm{gO}_{2} / \mathrm{m}^{3},
$$

for household wastewater, it is assumed that $\mathrm{k}_{1}=0.6,1 / \mathrm{d}$.

- Non-biodegradable organic suspension $\mathrm{X}_{\mathrm{I}}$ is calculated from the dependence:

$$
\mathrm{X}_{\mathrm{I}}=\mathrm{X}_{\mathrm{COD}}-\mathrm{X}_{\mathrm{S}}, \mathrm{gO}_{2} / \mathrm{m}^{3},
$$

where:

$\mathrm{X}_{\mathrm{COD}}$ - total concentration of dissolved organic substances in suspension.

\section{RESULTS AND DISCUSSION}

The test results of raw, mechanically treated and treated wastewater composition as mean values are presented in Table 2 . The organic contaminant values in raw wastewater were: $\mathrm{COD}=627 \div 739 \quad \mathrm{gO}_{2} / \mathrm{m}^{3}, \quad \mathrm{BOD}_{5}=307 \div 390 \quad \mathrm{gO}_{2} / \mathrm{m}^{3}$. Mechanically treated processes resulted in a decrease concentration of organic 
pollutants: $\mathrm{COD}=484 \div 600 \mathrm{gO}_{2} / \mathrm{m}^{3}$ and $\mathrm{BOD}_{5}=264 \div 273 \mathrm{gO}_{2} / \mathrm{m}^{3}$. The treated wastewater were as follows: $\mathrm{COD}=53 \div 67 \mathrm{gO}_{2} / \mathrm{m}^{3}$ and $\mathrm{BOD}_{5}=1.7 \div 4.2 \mathrm{gO}_{2} / \mathrm{m}^{3}$. The efficiency of the mechanicall treatment for COD was between 16.6 and $25.8 \%$ and for $\mathrm{BOD}_{5}$ from 11.5 to $32.3 \%$, while the totally efficiency for the WWTP was at the level $90.6 \div 91.5 \%$ for COD and $98.9 \div 99.5 \%$ for BOD $_{5}$.

Table 2. The organic contaminants in analyzed wastewater samples

\begin{tabular}{|c|c|c|c|c|c|}
\hline \multirow{2}{*}{$\begin{array}{c}\text { Wastewater } \\
\text { samples }\end{array}$} & \multicolumn{2}{|c|}{$\mathrm{COD}, \mathrm{gO}_{2} / \mathrm{m}^{3}$} & \multicolumn{2}{c|}{$\mathrm{BOD}_{5}, \mathrm{gO}_{2} / \mathrm{m}^{3}$} & $\mathrm{COD} / \mathrm{BOD}_{5}$ \\
\cline { 2 - 6 } & Son-filtred & $\begin{array}{c}\text { Filtred } \\
\text { samples }\end{array}$ & $\begin{array}{c}\text { Non-filtred } \\
\text { samples }\end{array}$ & $\begin{array}{c}\text { Filtred } \\
\text { samples }\end{array}$ & $\begin{array}{c}\text { Non-filtred } \\
\text { samples }\end{array}$ \\
\hline $\mathrm{P} 1$ & $695.1 \pm 59.4$ & $413.2 \pm 80.4$ & $352.7 \pm 42.1$ & $248.7 \pm 4.0$ & $1.97 \pm 0.07$ \\
\hline $\mathrm{P} 2$ & $543.8 \pm 58.3$ & $348.7 \pm 48.0$ & $269.0 \pm 4.6$ & $213.0 \pm 28.2$ & $2.02 \pm 0.23$ \\
\hline $\mathrm{P} 3$ & $61.1 \pm 7.1$ & $28.8 \pm 14.8$ & $2.8 \pm 1.3$ & $2.2 \pm 1.5$ & $25.29 \pm 12.81$ \\
\hline
\end{tabular}

P1 - raw wastewater, P2 - wastewater after primary settling tank, P3 - treated wastewater

In accordance with the procedure for determining the COD fraction given in point 3 , the concentrations of the individual fractions in the analyzed wastewater samples have been calculated. The results showing the concentrations of the individual fractions are presented in Table 3.

Table 3. COD fraction concentrations in wastewater samples

\begin{tabular}{|c|c|c|c|c|}
\hline \multirow{2}{*}{$\begin{array}{c}\text { Wastewater } \\
\text { samples }\end{array}$} & \multicolumn{4}{|c|}{ COD fractions, $\mathrm{gO}_{2} / \mathrm{m}^{3}$} \\
\cline { 2 - 5 } & $\mathbf{S}_{\mathbf{I}}$ & $\mathbf{S}_{\mathbf{S}}$ & $\mathrm{X}_{\mathbf{S}}$ & $\mathbf{X}_{\mathbf{I}}$ \\
\hline P1 & $28.8 \pm 14.8$ & $384.4 \pm 65.7$ & $203.4 \pm 48.2$ & $78.4 \pm 21.6$ \\
\hline P2 & $28.8 \pm 14.8$ & $319.9 \pm 34.6$ & $128.4 \pm 34.3$ & $66.6 \pm 47.1$ \\
\hline P3 & $28.8 \pm 14.8$ & $0.0 \pm 0.0$ & $4.7 \pm 2.1$ & $27.6 \pm 7.2$ \\
\hline
\end{tabular}

P1 -raw wastewater, P2 - wastewater after primary settling tank, P3 - treated wastewater

The test results shows that in raw wastewater, the most concentrated are fractions $S_{S}$ and $X_{S}$. Definitely lower are the concentrations of fractions $X_{I}$ and $S_{I}$. The highest concentrations among the calculated fractions characterised the dissolved, easily biodegradable fraction $\mathrm{S}_{\mathrm{s}}$. In raw wastewater, its concentration was between 314 and $443 \mathrm{gO}_{2} / \mathrm{m}^{3}$, while the $\mathrm{X}_{\mathrm{s}}$ fraction was in range $158 \div 254 \mathrm{gO}_{2} / \mathrm{m}^{3}$ and the $\mathrm{X}_{\mathrm{I}}$ fraction was from 59 to $102 \mathrm{gO}_{2} / \mathrm{m}^{3}$. In the mechanically treated wastewater the concentration of each fractions was at the level $\mathrm{S}_{\mathrm{s}}: 298 \div 360 \mathrm{gO}_{2} / \mathrm{m}^{3}, \mathrm{X}_{\mathrm{s}}: 90 \div 157 \mathrm{gO}_{2} / \mathrm{m}^{3}, \mathrm{X}_{\mathrm{I}}: 15 \div 107 \mathrm{gO}_{2} / \mathrm{m}^{3}$. In the treated wastewater samples the most concentrated are fractions $\mathrm{X}_{\mathrm{I}}$ and $\mathrm{S}_{\mathrm{I}}$. During the tests the lowest were the concentrations of fraction $S_{\mathrm{I}}$ from 14 to $43 \mathrm{gO}_{2} / \mathrm{m}^{3}$. The value of this fraction did not change in subsequent purification steps of mechanical biological treatment.

The determined percentage ratio of the individual fractions in wastewater samples are presented in Fig. 3. 


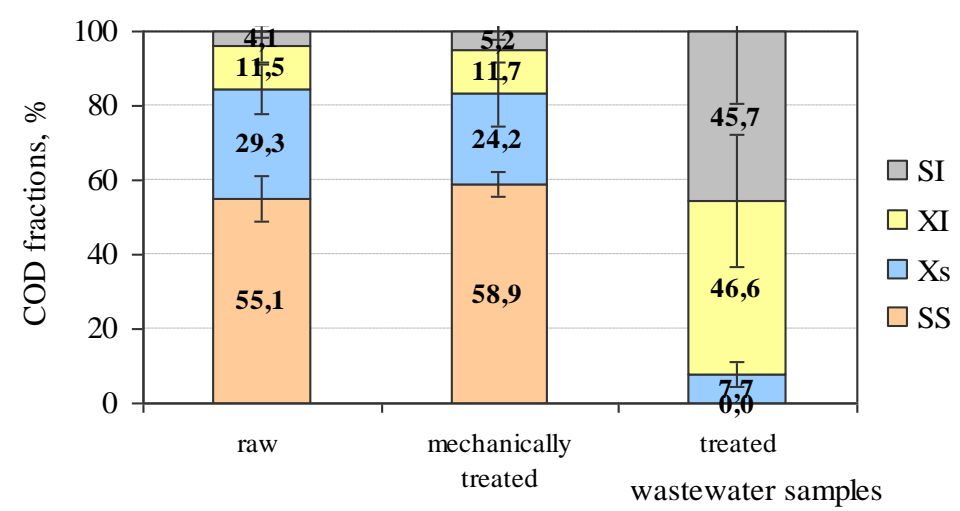

Fig. 3. The average percentage ratio of the individual fractions in total COD of analyzed wastewater samples

Among biodegradable fractions in raw wastewater, fraction $\mathrm{S}_{\mathrm{S}}$ which characterises dissolved, easily biodegradable substances constitutes between 50.0 and $61.7 \%$ of total COD is predominant. The ratio of fraction $\mathrm{X}_{\mathrm{S}}$ (insoluble, slowly biodegradable fraction) in total COD of the wastewater was between 22.0 and $34.4 \%$. The percentage content of fraction $X_{I}$ was at $8.0 \div 16.2 \%$. The lowest ratio, at $2.2 \div 6.0 \%$ in total COD of the tested raw wastewater, was that of fraction $\mathrm{S}_{\mathrm{I}}$. In mechanically treated wastewater samples the share of individual fractions was as follows: $\mathrm{S}_{\mathrm{S}}$ : $55.0 \div 61.7 \%, \mathrm{X}_{\mathrm{S}}: 15.0 \div 32.4 \%, \mathrm{X}_{\mathrm{I}}: 3.0 \div 17.8 \%$ and $\mathrm{S}_{\mathrm{I}} 2.8 \div 7.2 \%$, while in the treated wastewater was respectively: $\mathrm{X}_{\mathrm{I}}=31.4 \div 66.3 \%$, $\mathrm{S}_{\mathrm{I}}=25.9 \div 64.4 \%$ and $\mathrm{X}_{\mathrm{S}}=4.2 \div 11.2 \%$.

The concentration of biodegradable fractions $\operatorname{COD}(S)=S_{S}+X_{S}$, constituted over $80 \%$ of total COD in raw and mechanically treated wastewater (Fig. 4).

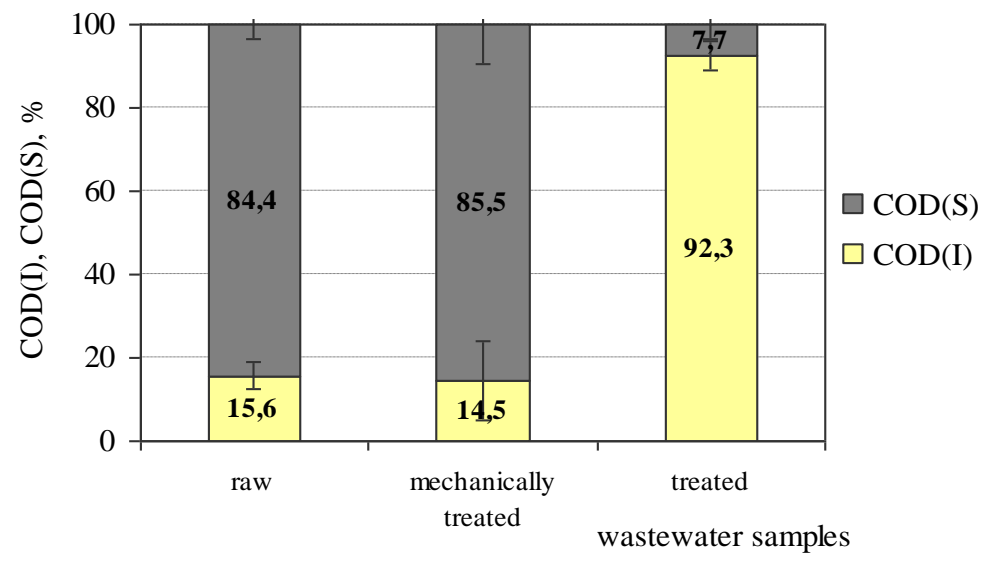

Fig. 4. The average percentage ratio of biodegradable $\operatorname{COD}(\mathrm{S})$ and non-biodegradable fractions COD (I) of analyzed wastewater samples 
In treated wastewater are dominated non biodegradable fractions $\mathrm{COD}(\mathrm{I})$ at the level $88.8 \div 95.85 \%$. Changes in the share of biodegradable and non-biodegradable fractions in wastewater samples, as well as $\mathrm{COD} / \mathrm{BOD}_{5}$ values changes (raw wastewater: about 2.0, treated wastewater over 15.0) confirm the good work of the wastewater treatment plant in terms of the removal of organic pollutants.

\section{CONCLUSIONS}

The presented test results are a basis for the formulation of final conclusions:

- The concentrations and percentage ratios of the individual COD fractions in raw wastewater determined in real conditions differ from the values assumed by the ASM models.

- The difference between the assumptions of the ASM1 and ASM2 models and the research results is the percentage of the $\mathrm{X}_{\mathrm{S}}$ and $\mathrm{S}_{\mathrm{S}}$ fractions in total COD. According to the models in raw wastewater the $\mathrm{X}_{\mathrm{S}}$ fraction dominates $(35 \div 75 \%)$, but the results of the research showed that in analyzed raw wastewater in the highest concentrations occur $\mathrm{S}_{\mathrm{s}}$ fraction $(50 \div 61.7 \%)$, then $\mathrm{X}_{\mathrm{S}}(20 \div 34.4 \%), \mathrm{X}_{\mathrm{I}}$ and $\mathrm{S}_{\mathrm{I}}$ fractions.

- The results of the research confirmed the assumptions in the models for the advantage of biodegradable fractions in raw wastewater, $\operatorname{COD}(\mathrm{S})=\mathrm{S}_{\mathrm{S}}+\mathrm{X}_{\mathrm{S}}$, constituted over $80 \%$ of total COD.

- The share of biodegradable and non-biodegradable fractions and $\mathrm{COD} / \mathrm{BOD}_{5}$ values in raw and treated wastewater indicate the good work of the analyzed wastewater treatment plant.

\section{REFERENCES}

1. Brdjanovic D., Van Loosdrecht M.C.M., Versteeg P., Hooijmans Ch.M., Alaerts G.J., Heijnen J.J.: Modeling COD, $N$ and $P$ removal in a full-scale WWTP Haarlem Waarderpolder. Water Research 34, No 3, (2000), 846-858.

2. Brun R., Kühni M., Siegrist H., Gujer W., Reichert P.: Practical identifiability of ASM2d parameters-systematic selection and tuning of parameter subsets. Water Research 36, (2002),113-4127.

3. Dulekgurgen E., Dogruel S., Karahan O., Orhon D.: Size distribution of wastewater COD fractions as an index for biodegradability. Water Research 40, (2006),273-282.

4. Ekama G.A., Dold P.,L., Marais G.v.R.: Procedures for determining influent COD. Fractions and the maximum species growth rate of heterotrophs in activated sludge systems. Wat.Sci.Tech. No.18, (1986),94-114. 
5. Gernaey K.V., Van Loosdrecht M.C.M., Henze M., Lind M.,Jorgensen S.B.: Activated sludge wastewater treatment plant modelling and simulation: state of art. Environmental Modelling\&Software 19, (2004), 763-783.

6. Gujer W., Henze M., Mino T., Matsuo T., Wentzel M.C., Marais G.v.R.: The activated sludge model no.2: Biological phosphorus removal, Wat. Sci. Tech. Vol.31, No.2, (1995),1-11.

7. Gujer W., Henze M., Mino T., Van Loosdrecht M.: Activated sludge model No.3. (1999), Pergamon.

8. Henze M., Grujer W., Mino T., Matsuo T., Wentzel M.C., Marais Gv.R., Van Loosdrecht M.C.M.: Activated Sludge Model No.2D ASM2D. Pergamon, Water Science and Technology 39, No.1, (1999),165-182.

9. Henze M., Gujer W., Mino T., Matsuo T., Wentzel M.C., Marais G.v.R.: Wastewater and biomass characterization for the activated sludge model no.2: Biological phosphorus removal, Wat. Sci. Tech. Vol.31,No.2, (1995), 13-23.

10. Henze M., Gujer W., Mino T., Van Loosdrecht M.: Activated sludge models ASM1, ASM2, ASM2d, ASM3. Iwa Task Group On Mathematical Modelling For Design And Operation Of Biological Wastewater Treatment, London 2007.

11. Hu Z., Chandran K., Smets B.F., Grasso D.: Evaluation of rapid physicalchemical method for the determination of extant soluble COD. Water Research 36, (2002), 617-624.

12. Karahan ö., Dogruel S., Dulekgurgen E., Ohron D.: COD fraction of tannery wastewaters-Particle size distribution, biodegradability and modeling. Water Research 42, (2008), 1083-1092.

13. Lagarde F., Tusseau-Vuillemin M-H., Lessard P., Héduit A., Dutrop F., Mouchel J-M.: Variability estimation of urban wastewater biodegradable fractions by respirometry. Water Research 39, (2005), 4768-4778.

14. Mąkinia J. Wells S.A.: A general model of the activated sludge reactor with dispersive flow-I.model development and parameter estimation. Water Research Vol.34, No.16. (2000) 3987-3996.

15. Melcer H., Dold P.L., Jones R.M., Bye Ch.M., Takacs I., Stensel H.D., Wilson A.W., Sun P., Bury S.: Treatment Processes and Systems. Methods for Wastewater Characterization in Activated Sludge Modeling. Water Environment Research Foundation, 2003.

16. Melcer H., Dold P.L., Jones R.M., Bye Ch.M., Takacs I., Stensel H.D., Wilson A.W., Sun P., Bury S.: Treatment Processes and Systems. Methods for Wastewater Characterization in Activated Sludge Modeling, Water Environment Research Foundation 2003. 
17. Myszograj S.: Charakterystyka frakcji ChZT w procesach mechanicznobiologicznego oczyszczania ścieków. II Kongres Inżynierii Środowiska, Monografie Komitetu Inżynierii Środowiska PAN, 39 (2005), Lublin.

18. Nopens I., Badstone D.J., Copp J. B., Jeppson U., Volcke E., Alex, Vanrollehghem P.A.: An ASM/ADM model interface for dynamic plant-wide simulation. Water Research 43, (2009),1913-1923.

19. Orhon D., Ates E., Sözen S., Cokgör E.U.: Characterization and Cod fractionation of domestic wastewaters. Environmental Pollution, vol.95, no.2. (1997), 191-204.

20. Pasztor I., Thury P., Pulai J.: Chemical oxygen demand fractions of municipal wastewater for modeling of wastewater treatment. International Journal of Environmental Science and Technology, Vol.6,No.1, (2009),51-56.

21. Petersen B., Gernaey K., Henze M., Vanrolleghem P.A.: Calibration of activated sludge models: A critical review of experimental designs Biotechnology for the environment: soil remediation. Red. S.N. Agathos, W. Reineke. Kluwer Academic Publishers, Dordrecht 2002.

22. Płuciennik-Koropczuk E.: Frakcje ChZT miara skuteczności oczyszczania ścieków. Gaz, Woda i Technika Sanitarna nr 7-8, (2009), 11-13.

23. Sadecka Z., Myszograj S.: Frakcje ChZT w procesach mechanicznobiologicznego oczyszczania ścieków na przykładzie oczyszczalni ścieków w Sulechowie. Rocznik Ochrona Środowiska T. 6, (2004), 233-244.

24. Sadecka Z., Płuciennik-Koropczuk E.: Frakcje ChZT ścieków w mechaniczno-biologicznej oczyszczalni. Rocznik Ochrona Środowiska -, T. 13 cz.2, (2011), 1157-1172.

25. Spérandio M., Etienne P.: Estimation of wastewater biodegradable COD fractions by combining respirometric experiments in various SO/XO ratios. Water Research 34.No.4, (2000),1233-1246.

26. Vandekerekhove A., Moerman W., Van Hulle S.W.H.: Full-scale modeling of a food industry wastewater treatment plant in view of process upgrade, Chemical Engineering Journal 135, (2008), 185-194.

27. Vanrolleghem P.A., Spanjers H., Petersen B., Ginestet P., Takacs I.: Estimating Combination of activated sludge model no.1 parameters and components by respirometry, Wat. Sci.Tech., (1999), 195-214.

28. Wytyczna ATV - DVWK - A 131 P., Wymiarowanie jednostopniowych oczyszczalni ścieków z osadem czynnym. Wydawnictwo Seidel - Przywecki, 2002. 


\title{
FRAKCJE ChZT W MECHANICZNO-BIOLOGICZNEJ OCZYSZCZALNI ŚCIEKÓW
}

\author{
Streszczenie
}

W artykule przedstawiono wyniki badań dotyczące wyznaczania frakcji ChZT w ściekach surowych, mechanicznie oczyszczonych oraz oczyszczonych. Obiektem badań była mechaniczno-biologiczna oczyszczalnia ścieków o wielkości powyżej 20000 RLM. Uzyskane wyniki porównano z założeniami modeli biokinetycznych ASM. W badaniach wyznaczono następujące frakcje: rozpuszczone substancje organiczne, biologicznie nierozkładalne $\mathrm{S}_{\mathrm{I}}$, rozpuszczone substancje organiczne, biologicznie łatwo rozkładalne $\mathrm{S}_{\mathrm{S}}$, substancje organiczne $\mathrm{w}$ zawiesinie, biologicznie wolno rozkładalne $\mathrm{X}_{\mathrm{S}}$ oraz substancje organiczne $\mathrm{w}$ zawiesinie, biologicznie trudno rozkładalne $\mathrm{X}_{\mathrm{I}}$. Metodyka wyznaczania frakcji ChZT została opracowana w oparciu o wytyczne ATV-131. Wyznaczone w badaniach wartości procentowego udziału frakcji w badanych ściekach surowych różnią się od założeń modeli ASM.

Słowa kluczowe: ścieki, frakcje ChZT, modele ASM, substancje organiczne biodegradowalne i niebiodegradowalne

Editor received the manuscript: 08.11.2016 